\title{
O-O bond formation mediated by a hexanuclear iron complex supported on a stannoxane core.
}

\author{
SubrataKundu, ${ }^{[a]}$ Eduard Matito, ${ }^{[b]}$ Stephan Walleck, ${ }^{[c]}$ Florian F. Pfaff, ${ }^{[\mathrm{a}]}$ Florian Heims, ${ }^{[\mathrm{a}]}$ \\ Battist Rábay, ${ }^{[\mathrm{a}]}$ Josep M. Luis, ${ }^{[\mathrm{d}]}$ Anna Company, ${ }^{[\mathrm{el}}$ Beatrice Braun, ${ }^{[\mathrm{a}]}$ Thorsten Glaser, ${ }^{[\mathrm{cl}]}$ and \\ Kallol Ray*[a]
}

In recent years, much attention has been focused on the incorporation of redox-active transition-metal complexes into the dendrimer structure owing to their potential applications in various fields. ${ }^{1}$ Also, the antenna-like structure of the dendrimers, in many cases, was found to provide an ideal organization for these chromophores and redox centers to work in synergistic ways in carrying out a number of important transformations. ${ }^{2}$ For example, an extensive cooperative effect between the $\mathrm{Cu}$ centers was observed during the cleavage of supercoiled DNA catalyzed by a hexanuclear Cu-porphyrin complex, supported on a stannoxane core. ${ }^{2 b}$

The above-mentioned hexaporphyrin assembly was synthesized in high yields and in a single step utilizing the organostannoxane approach, whereby n-butyl stannoic acid was made to react with the corresponding porphyrin carboxylic acid in 1:1 stoichiometry in benzene; ${ }^{2 b}$ the molecular structure of the ligand was established on the basis of ${ }^{119} \mathrm{Sn}$ NMR and DFT calculations. In the present paper we report the synthesis of a nonhemehexanucleating ligand (1) supported on a drum-like stannoxane central core utilizing the same organostannoxane approach (Scheme 1). $\mathbf{1}$ is characterized by X-ray diffraction, ${ }^{119}$ Sn NMR, and infrared methods. Most importantly, we show that the $\mathrm{Fe}^{\mathrm{II}}$-metalatedhexa non-heme assembly, 2, in the presence of 2-(tert-butylsulfonyl)-iodosylbenzene ( ${ }^{\mathrm{S}} \mathrm{PhIO}$ ), performs a rare $\mathrm{O}-\mathrm{O}$ bond formation reaction, ${ }^{3}$ thereby generating a

[a] Humboldt-Universität zu Berlin, Institut für Chemie, Brook Taylor-Straße 2, D-12489 Berlin, Germany

Fax: (+49) 3020937387

E-mail: kallol.ray@chemie.hu-berlin.de

[b] Institute of Physics, University of Szczecin, Wielkopolska 15, 70451 Szczecin, Poland

[c] Lehrstuhl für Anorganische Chemie I, Fakultät für Chemie, Universität Bielefeld, universitätstr. 25, D-33615 Bielefeld, Germany

[d] Institut de Química Computacional, Department de Química, Facultat de Ciències, Universitat de Girona, 17071 Girona, Spain

[e] Institute of Chemistry: MetalorganicsandInorganicmaterials, Technische Universität Berlin, Straße des 17. Juni 135, Sekr. C2, D-10623 Berlin, Germany.

Supporting information for this article is available on the WWW under http://www.chemeurj.org/ or from the author.
$\mathrm{Fe}^{\mathrm{III}}-\left(\mathrm{O}_{2}{ }^{--}\right) \mathrm{Fe}^{\mathrm{II}}$ superoxo unit. Such a metal mediated $\mathrm{O}-\mathrm{O}$ bond formation step is considered to be the most critical part of dioxygen evolution in photosystem $\mathrm{II}^{4}$ and hence plays a vital role in the context of attaining a clean renewable energy source. ${ }^{5}$

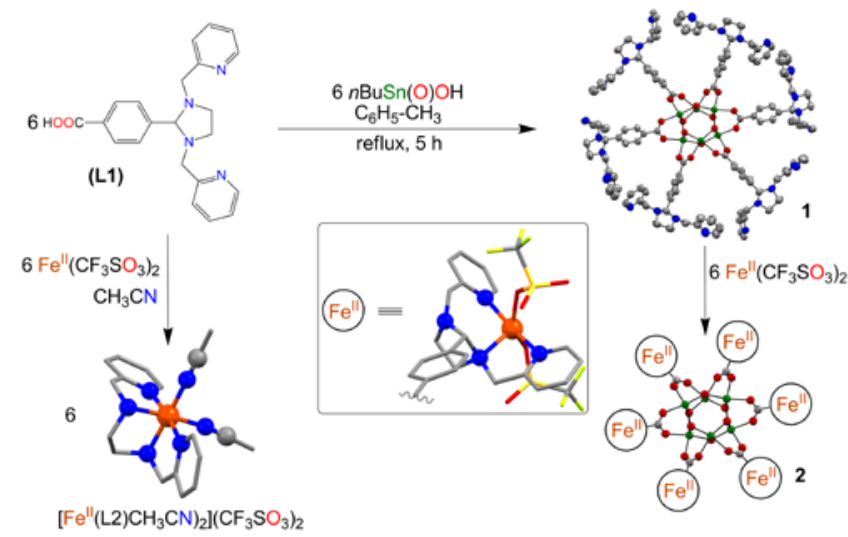

Scheme 1.Scheme showing the synthesis of the complexes. Hydrogen atoms and the $n$-butyl groups on tin have been omitted for clarity. Color conventions: N: blue; C: grey; O: red; Fe: orange, and $\mathrm{Sn}$ : green. Molecular structures of the hexanuclearligand $\mathbf{1}$ and the complex $\left[\mathrm{Fe}^{\mathrm{II}}(\mathrm{L} 2)\left(\mathrm{CH}_{3} \mathrm{CN}\right)_{2}\right]^{2+}$ are determined by X-ray crystallography. Structure of $\mathbf{2}$ is proposed based on ICP-MS, ${ }^{119} \mathrm{Sn}-\mathrm{NMR},{ }^{19} \mathrm{~F}-\mathrm{NMR}$ IR, Mössbauer and DFT methods (see text).

The condensation reaction (Scheme 1 ) of equimolar amounts of $n$-butyl stannoic acid and 4-(1,3-bis(2-pyridylmethyl)-2imidazolidinyl)benzoic acid (L1) in toluene afforded a pale yellow solid $\mathbf{1}$, whose molecular structure (Scheme 1$)^{6}$ shows a giant-wheel arrangement of the six non-heme ligand units with a drum-like stannoxane central core serving as the structural support for the hexanucleating assembly. The general features of the stannoxane framework are found to be similar to the other structurally characterized drum-shaped molecules and have a crystallographic $\mathrm{S}_{6}$ symmetry, so that six tin atoms are crystallographically and chemically equivalent. ${ }^{7}{ }^{119} \mathrm{Sn}$ NMR spectrum of 1 exhibits a sharp singlet at $-482.4 \mathrm{ppm}$ (Fig. S1 top), which is the characteristic signature for a hexameric organostannoxane drum containing a $\mathrm{Sn}_{6} \mathrm{O}_{6}$ core. $^{7}$ The infrared spectrum shows a symmetric doublet at $1590 \mathrm{~cm}^{-1}$ and $1605 \mathrm{~cm}^{-1}$ for the carboxyl absorption (vCoo), ${ }^{7}$ and a strong band at $624 \mathrm{~cm}^{-1}$ assigned to vsn-o $^{7}$ for the drum core (Fig. S2 top). 
Before describing the hexameric ligand, the chemistry of the monomeric ligand $\mathbf{L 1}$ was first explored. Reaction of $\mathbf{L} \mathbf{1}$ with 1 eqv $\mathrm{Fe}(\mathrm{OTf})_{2}$ in $\mathrm{CH}_{2} \mathrm{Cl}_{2}$ resulted in the formation of a yellow oil. ESI-MS analysis (Fig. S3 top) showed a signal at $\mathrm{m} / \mathrm{z}=447.1$, with an isotope distribution pattern consistent with its formulation as $\left[\mathrm{Fe}^{\mathrm{II}}(\mathrm{L} 2)(\mathrm{OTf})\right]^{+}$, where L2 is the ligand formed upon opening of the central aminal ring of $\mathbf{L} \mathbf{1}$ (Scheme 1). Similar results were reported previously for related systems. ${ }^{8}$ Slow evaporation of the solvent from a $\mathrm{CH}_{3} \mathrm{CN}$ solution of the yellow oil resulted in deep red crystals, which when analysed by X-ray crystallography established the molecular structure as $\left[\mathrm{Fe}^{\mathrm{II}}(\mathrm{L} 2)\left(\mathrm{CH}_{3} \mathrm{CN}\right)_{2}\right](\mathrm{OTf})_{2}$ (Scheme 1, Fig. S4, Table S7). ${ }^{6}$
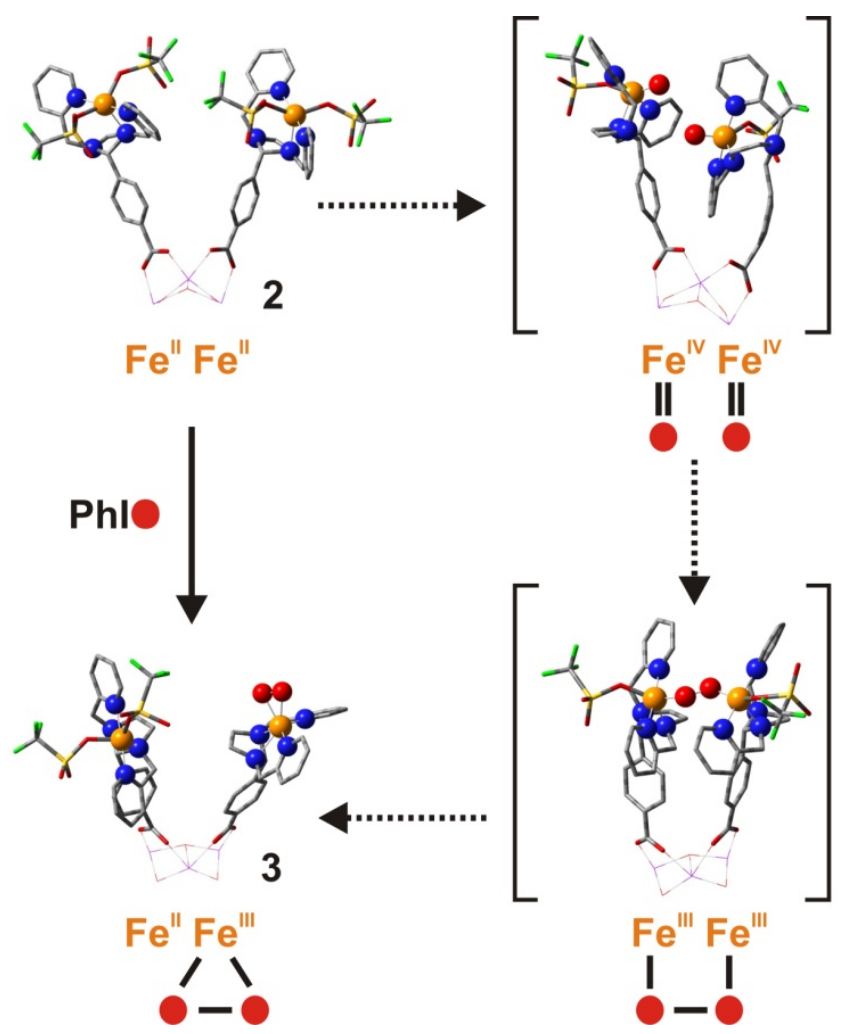

Scheme 2. Plausible mechanism for the O-O bond formation reaction carried out by 2. The $\mathrm{Fe}^{\mathrm{IV}}(\mathrm{O})$ intermediates are proposed on the basis of reactivity, kinetics, and infrared studies (see text). The peroxo complex is an obvious precursor to the superoxo unit in 3. Structures of 3, iron(IV) oxo and peroxo complexes were optimized by DFT calculations, ${ }^{12}$ using a simplified model where the effect of the stannoxane core, which was not included in the model, was simulated by freezing the position of the carboxylate oxygens and by considering only two of the six iron centers. Structure of $\mathbf{2}$ is based on the DFT calculated geometry of the $\mathrm{S}=2$ monomeric unit. For details about the calculations see SI. Color conventions: N: blue; C: grey; O: red; Fe: orange; Sn: violet; and F: green.

The hexanucleating ligand 1 when reacted with 6 eqv of $\mathrm{Fe}(\mathrm{OTf})_{2}$ in $\mathrm{CH}_{2} \mathrm{Cl}_{2}$ yielded the metalated species 2 as a yellowish-green powder (60\% yield). Interestingly, the ESI-MS spectrum of 2 did not show any signal at $\mathrm{m} / \mathrm{z}=$ 447.1 corresponding to the decomposition product $\left[\mathrm{Fe}^{\mathrm{II}}(\mathrm{L} 2)(\mathrm{OTf})\right]^{+}$after aminal ring opening. ${ }^{9}$ The iron content of $\mathbf{2}$, determined by the inductively coupled plasma mass spectrometry (ICP-MS) method together with the elemental analysis, established the presence of six iron atoms per hexameric ligand 2, with two triflates associated with each iron. A major doublet with an isomer shift $\delta=$ $1.10 \mathrm{~mm} \mathrm{~s}^{-1}$ and quadrupole splitting $\Delta \mathrm{E}_{\mathrm{Q}}=2.80 \mathrm{~mm} \mathrm{~s}^{-1}$ in the zero-field Mössbauer spectrum of $\mathbf{2}$ demonstrates equivalent high-spin $\mathrm{Fe}^{\mathrm{II}}$ centers in a five coordinate geometry. ${ }^{10,11}$ Based on the DFT calculation ${ }^{12}$ the most stable coordination environment of the $\mathrm{Fe}^{\mathrm{II}}$ centers in 2 corresponds to a distorted trigonal bipyramidal geometry (Scheme 2, Fig. S5 and Table S1) with two equatorial triflate ligands. The ligand L1 acts as a tridentate ligand, with one of the nitrogens of the 5-membered imidazolidinyl ring remaining out of the coordination sphere. The calculated Mössbauer parameters $\left(\delta=1.17 \mathrm{~mm} \mathrm{~s}^{-1} ; \Delta \mathrm{E}_{\mathrm{Q}}=\right.$ $\left.3.17 \mathrm{~mm} \mathrm{~s}^{-1}\right)^{11}$ for the DFT calculated coordination environment of the $\mathrm{Fe}^{\mathrm{II}}$ centers in $\mathbf{2}$ is found to be in good agreement with the experiment. The small deviation of $13 \%$ in the calculated quadrupole splitting is typical of DFT functionals. ${ }^{13}$ Consistent with the DFT calculated structure, ${ }^{19} \mathrm{~F}$ NMR spectra of 2 at $-20{ }^{\circ} \mathrm{C}$ exhibits a single peak at +15 ppm corresponding to the triflate anions, which are bound to the Fe(II) high spin centers. ${ }^{14 a}{ }^{119} \mathrm{Sn}$ NMR of $\mathbf{2}$
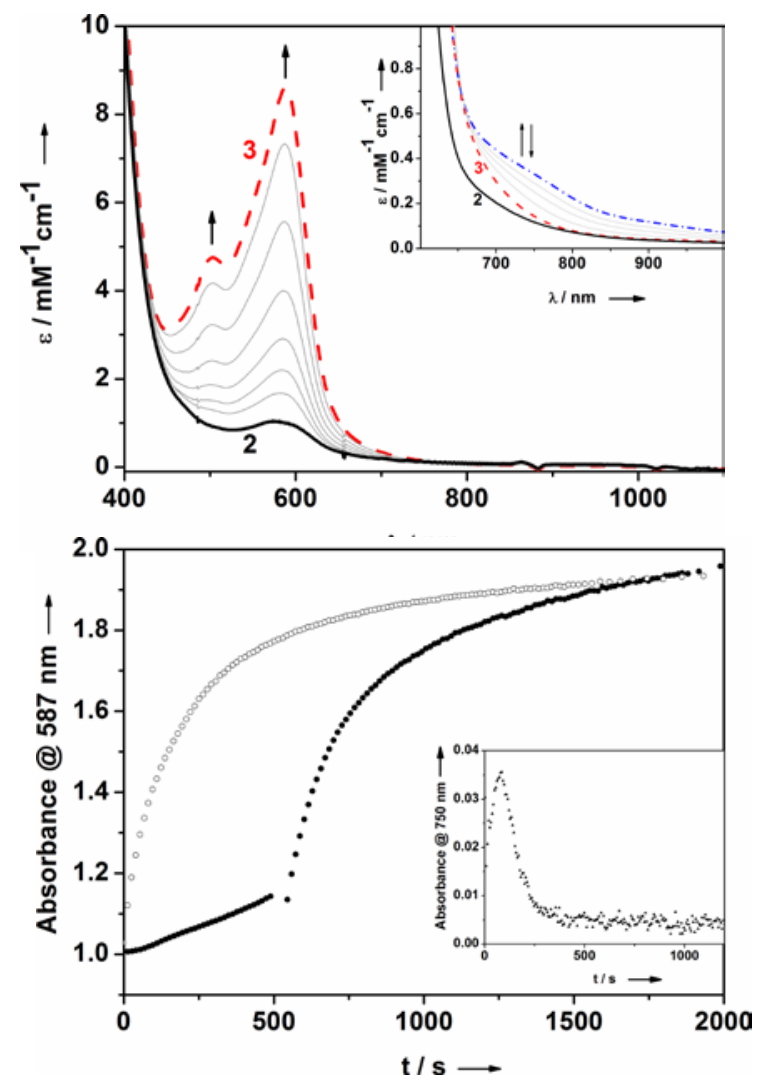

Figure 1. Top: UV-vis spectra of 2 (solid black line) and 3 (red dashed line) in $\mathrm{CH}_{2} \mathrm{Cl}_{2}$ at $25{ }^{\circ} \mathrm{C}$. The intermediate spectra show the conversion of $\mathbf{2}$ to 3 upon addition of ${ }^{\mathrm{s}} \mathrm{PhIO}(1 \mathrm{eq})$. The inset shows the conversion of $\mathbf{2}$ (black trace) to $\mathbf{3}$ (red trace) at $-80{ }^{\circ} \mathrm{C}$ via the intermediate formation of a species with $\lambda_{\max }=750 \mathrm{~nm}$ (blue trace). Bottom: Plot of absorbance change at $587 \mathrm{~nm}$ against time during the reaction of $2\left(0.23 \mathrm{mM}\right.$ ) with $m$ CPBA (open circle, $\mathrm{k}_{1}=5.3 \times 10^{-3} \mathrm{~s}^{-1}$ ) and ${ }^{\text {SPhIO (closed }}$ circle; $\mathrm{k}_{1}=0.4 \times 10^{-3} \mathrm{~s}^{-1}$ without $n \mathrm{Bu}_{4}$ NOAc addition for the initial $500 \mathrm{~s} ; \mathrm{k}_{1}=5.0$ $\mathrm{x} 10^{-3} \mathrm{~s}^{-1}$ in presence of $n \mathrm{Bu} 4 \mathrm{NOAc}$ ) in $\mathrm{CH}_{2} \mathrm{Cl}_{2}$ at $25{ }^{\circ} \mathrm{C}$. Inset: Plot of absorbance change at $750 \mathrm{~nm}$ against time during the reaction of 2 with ${ }^{\mathrm{S}} \mathrm{PhIO}$ at $-80{ }^{\circ} \mathrm{C}$ in $\mathrm{CH}_{2} \mathrm{Cl}_{2}$.

in $\mathrm{CD}_{2} \mathrm{Cl}_{2}$ does not exhibit any peak in the range -475 to -490 ppm, which can be attributed to paramagnetic line broadening in the presence of high-spin $\mathrm{Fe}^{\mathrm{II}}$ ions. In $\mathrm{CD}_{3} \mathrm{CN}$, however, the $\mathrm{Fe}^{\mathrm{II}}$ centers of 2 become low-spin owing to $\mathrm{CD}_{3} \mathrm{CN}$-binding, as evident from the appearance of the characteristic sharp singlet feature of the drum-like stannoxane core at $-485.5 \mathrm{ppm}$ in the ${ }^{119} \mathrm{Sn}$ NMR (Fig. S1 bottom), which is also supported by 
Mössbauer. ${ }^{11}$ Thus, the tin core supporting the hexa non-heme assembly is retained during the metalation of $\mathbf{1}$ to form $2 .{ }^{15}$

The mononuclear nonheme $\mathrm{Fe}^{\mathrm{IV}}$-oxo complexes, which act as models for the high-valent $\mathrm{Fe}^{\mathrm{IV}}$-oxo intermediates found in many nonheme iron enzymes that activate oxygen, ${ }^{16}$ can in general be prepared by the reaction of the $\mathrm{Fe}^{\mathrm{II}}$ precursors with an oxygen atom donor like iodosobenzene. ${ }^{14}$ They exhibit a signature nearIR band in the absorption spectra, which arises from the low-lying ligand field transitions of an $\mathrm{S}=1 \mathrm{Fe}^{\mathrm{IV}}$ center. ${ }^{14}$ The reaction of $\mathbf{2}$ in $\mathrm{CH}_{2} \mathrm{Cl}_{2}$ with ${ }^{\mathrm{s}} \mathrm{PhIO}$ at $25{ }^{\circ} \mathrm{C}$, however, led to a deep purple complex 3, whose electronic absorption spectrum with absorption maxima $\lambda_{\max }\left(\varepsilon_{\max }, \mathrm{M}^{-1} \mathrm{~cm}^{-1}\right)$ centered at $500 \mathrm{~nm}$ (5150) and 587 $\mathrm{nm}$ (8580) (Fig. 1 top) lacked the characteristic near-IR feature of the $\mathrm{Fe}^{\mathrm{IV}}$-oxo complexes. When the same reaction was done at -80 ${ }^{\circ} \mathrm{C}$ instead, a transient intermediate (Fig. 1 top inset) was detected during the conversion of $\mathbf{2}$ to 3 ; the time-trace of the reaction monitored at $750 \mathrm{~nm}$ shows a sharp increase followed by a slow decrease (Fig. 1 bottom inset). This together with our infrared results (see below) may indicate the involvement of a $\mathrm{Fe}^{\mathrm{IV}}$-oxo intermediate during the generation of $\mathbf{3}$. Reaction of $\mathbf{2}$ with dioxygen at $25{ }^{\circ} \mathrm{C}$ in $\mathrm{CH}_{2} \mathrm{Cl}_{2}$ could also generate $\mathbf{3}$ in near quantitative yields. No intermediate was, however, observed in this case.

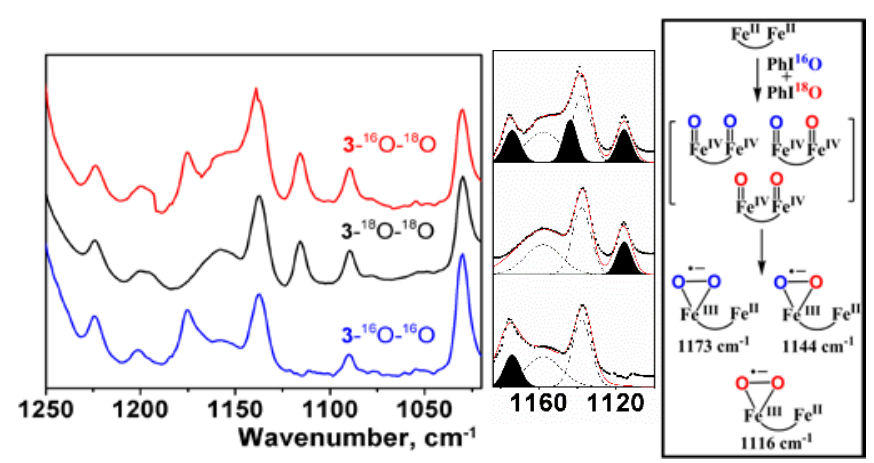

Figure 2. Left: The $v(\mathrm{O}-\mathrm{O})$ region in the infrared spectra of 3 generated from the reaction of 2 with ${ }^{\mathrm{s}} \mathrm{PhI}{ }^{16} \mathrm{O}$ (blue line), ${ }^{\mathrm{s}} \mathrm{PhI}^{18} \mathrm{O}$ (black line), and a 1:1 mixture of ${ }^{5} \mathrm{PhI}^{16} \mathrm{O}$ and ${ }^{5} \mathrm{PhI}^{18} \mathrm{O}$ (red line). Middle: Gaussian deconvulation of the bands in the 1100-1185 $\mathrm{cm}^{-1}$ region (Experimental spectra are shown as dotted lines and simulation as red bold lines). The oxygen sensitive bands at 1173, 1144, and 1116 $\mathrm{cm}^{-1}$ are shaded in black; bands at $1158 \mathrm{~cm}^{-1}$ and $1138 \mathrm{~cm}^{-1}$ are not sensitive to $18-\mathrm{O}$ labelling and are represented by dashed lines. Right: Scheme showing the formation of the mixed label superoxide in presence of $1: 1^{\mathrm{S}} \mathrm{PhI}^{16} \mathrm{O}$ and ${ }^{\mathrm{s}} \mathrm{PhI}{ }^{18} \mathrm{O}$.

In the infrared (IR) vibrational spectrum of 3 (Fig. 2), an oxygen sensitive band at $1173 \mathrm{~cm}^{-1}\left(3-{ }^{16} \mathrm{O}-{ }^{16} \mathrm{O}\right.$; blue trace) was observed, which shifted to $1116 \mathrm{~cm}^{-1}\left(3^{-18} \mathrm{O}-{ }^{18} \mathrm{O}\right.$; black trace) in the corresponding ${ }^{18} \mathrm{O}$ labelled 3 . The isotope shift of $57 \mathrm{~cm}^{-1}$ agrees well with the calculated $\left(67 \mathrm{~cm}^{-1}\right)^{12}$ and experimentally observed (Table S2) shifts for the O-O bond stretching vibrational mode of a selected number of different transition metalsuperoxides that are known in the literature. When $\mathbf{3}$ was generated by the reaction of 2 with a $1: 1{ }^{\mathrm{s}} \mathrm{PhI}^{16} \mathrm{O}$ : ${ }^{\mathrm{s}} \mathrm{PhI}{ }^{18} \mathrm{O}$ mixture, the IR spectrum showed the presence of three oxygen sensitive bands at 1173,1144 , and $1116 \mathrm{~cm}^{-1}$ with the respective intensity ratios of $1: 1.3: 1$ (red trace). The additional band at $1144 \mathrm{~cm}^{-1}$ is assigned to the $\mathrm{O}-\mathrm{O}$ stretch of the mixed label $\left(3^{-16} \mathrm{O}-{ }^{18} \mathrm{O}\right)$ species. Thus, the values of the stretching frequencies found in the infrared studies suggest the presence of a superoxo unit in 3 . Moreover, the presence of the $3{ }^{-16} \mathrm{O}-{ }^{18} \mathrm{O}$ stretch at $1144 \mathrm{~cm}^{-1}$ may imply the intermediacy of $\mathrm{Fe}^{\mathrm{IV}}$-oxo complexes (Fig. 2 right), ${ }^{17}$ which is also corroborated by UV-Vis studies. A single $3-{ }^{16} \mathrm{O}-{ }^{18} \mathrm{O}$ stretch ${ }^{18}$ also implies that the O-O bond in $\mathbf{3}$ is symmetric, which may point towards a side-on binding mode of the superoxo unit. DFT calculations on $\mathbf{3}$ also favour the side-on binding mode (Fig. S6 and Table S3) over the alternative end-on mode (Fig. S7 and Table S4) by $10 \mathrm{kcal} \cdot \mathrm{mol}^{-1}$.9,15,19 Moreover, 3 is found to be EPR silent similar to 2 .

The time-trace for the formation of the deep purple complex 3 monitored at $587 \mathrm{~nm}$ by reaction of 2 with ${ }^{\mathrm{s}} \mathrm{PhIO}$ is shown in Fig.1 bottom. It can be approximately fitted to a first-order plot with a rate constant $k_{1}$ of $0.44 \times 10^{-3} \mathrm{~s}^{-1}$ at $25^{\circ} \mathrm{C}$. The value of $k_{1}$ was found to be independent on the starting concentration of 2 (0.2 - $1.2 \mathrm{mM}$ ), which points towards an intramolecular mechanism (intermolecular processes show concentrationdepending kinetics). Interestingly, when the above reaction was performed in the presence $n \mathrm{Bu}_{4} \mathrm{~N}(\mathrm{OAc})$, a ten-fold increase $\left(k_{1}=\right.$ $5 \times 10^{-3} \mathrm{~s}^{-1}$ ) in the first-order rate was observed. ${ }^{20}$ However, when dioxygen was used as the oxidant, no rate enhancement occurred with $n \mathrm{Bu}_{4} \mathrm{~N}(\mathrm{OAc})$. We therefore attribute the increase in the rate of conversion of $\mathbf{2}$ to $\mathbf{3}$ to the bridging ability of the acetate anion, which helps to bring the two iron units close to each other, thereby ensuring efficient $\mathrm{O}-\mathrm{O}$ bond formation. Consistent with our proposition, meta-chloroperbenzoic acid (mCPBA) also generated $\mathbf{3}$ from $\mathbf{2}$ at a rate similar to what was observed for the ${ }^{\text {s}} \mathrm{PhIO} /$ acetate mixture. In this case the chlorobenzoate anion, formed by the heterolytic O-O cleavage of the initially formed cholorobenzoylperoxo species (Scheme S2), plays the same role as acetate anions by bridging the iron oxo units for efficient $\mathrm{O}-\mathrm{O}$ bond formation reaction. ${ }^{14 c}$

The reactivity of $\mathbf{3}$ with different substrates was also explored at $25^{\circ} \mathrm{C}$. Reaction with 1 eqv $\mathrm{CF}_{3} \mathrm{CO}_{2} \mathrm{H}$ led to the decay of the 587 and $500 \mathrm{~nm}$ bands and the appearance of a new band at 415 $\mathrm{nm}$ (Fig. S8). $\mathrm{H}_{2} \mathrm{O}_{2}$ was released in $>65 \%$ yield (see SI for details), thereby confirming the presence of $\mathrm{O}-\mathrm{O}$ bonds in 3 . Complex 3 reacted with cyclohexane carboxaldehyde (CCA), and benzoyl chloride with a second order rate constant $\left(k_{2}\right)$ of 0.001 $\mathrm{M}^{-1} \mathrm{~s}^{-1}$ and $0.002 \mathrm{M}^{-1} \mathrm{~cm}^{-1}$, respectively (Fig. S9). Cyclohexene and benzoic acid were obtained in the respective yields of $30 \%$ and $33 \%$. 3 also exhibited typical superoxide reactivity ${ }^{21}$ by abstracting hydrogen atoms from 2,2,6,6-tetramethylpiperidine-1hydroxy (TEMPOH) and 2,6-di-tert-butyl phenol, thereby forming the TEMPO' radical (33\% yield) and 2,2',6,6'-tetra-tertbutyl-4,4'-biphenol, respectively.

Efforts were also made to trap the transient oxoiron(IV) intermediate during the conversion of $\mathbf{2}$ to 3 . Thus, the reaction of 2 with ${ }^{\mathrm{P} h I O}$ at $-80{ }^{\circ} \mathrm{C}$ in the presence of excess of benzyl alcohol led to the generation of $\mathbf{3}$ at only $40 \%$ of its original level (Fig. S10). Benzaldehyde was generated in $50 \%$ yield. Such reactions are typical of oxoiron(IV) complexes. $^{14}$ Interestingly, dihydroanthracene or 1,3 cyclohexadiene $(\mathrm{BDE}=77 \mathrm{kcal} / \mathrm{mol}),{ }^{22}$ which have $\mathrm{C}-\mathrm{H}$ bond dissociation energies similar to that of benzyl alcohol $(\mathrm{BDE}(\mathrm{C}-\mathrm{H})=80 \mathrm{kcal} / \mathrm{mol}$; $\operatorname{BDE}(\mathrm{O}-\mathrm{H})=101$ $\mathrm{kcal} / \mathrm{mol})^{22}$ were completely inefficient in trapping the oxoiron(IV) intermediate generated during the conversion of $\mathbf{2}$ to 3. Thus the reaction of the benzyl alcohol probably proceeds by the preferential activation of the $\mathrm{O}-\mathrm{H}$ bond rather than the $\mathrm{C}-\mathrm{H}$ bond or by a hydride transfer mechanism. ${ }^{23}$ 2,4,6-tri-tert-butyl phenol (20 equiv) was also found to be capable of intercepting about $40 \%$ of the oxidant responsible for the $\mathrm{O}-\mathrm{O}$ bond formation 
reaction, thereby yielding 2,4,6-tri-tert-butyl phenoxyl radical in $45 \%$ yield. ${ }^{24}$

In summary, we have demonstrated the intramolecular O-O bond formation reaction mediated by a hexanuclear $\mathrm{Fe}^{\mathrm{II}}$ complex 2 using iodosobenzene as the oxygen source. Based on our studies, the $\mathrm{O}-\mathrm{O}$ bond-forming reaction can be best construed by a mechanism whereby the oxygen progresses through oxo, peroxo, and superoxo states. ${ }^{25} \mathrm{Fe}^{\mathrm{IV}}$-oxo complexes are proposed as the plausible intermediates on the basis of a) observance of the mixed labeled $3-{ }^{16} \mathrm{O}-{ }^{18} \mathrm{O}$ stretch at $1144 \mathrm{~cm}^{-1}$ when 3 was generated with a ${ }^{5} \mathrm{PhI}^{16} \mathrm{O}$ : ${ }^{\mathrm{s}} \mathrm{PhI}{ }^{18} \mathrm{O}$ (1:1) mixture (Fig. 2); b) kinetics of the formation of 3, which shows the involvement of an intermediate with a characteristic band at $750 \mathrm{~nm}$; and c) interception by benzylalcohol and 2,4,6-tri-tert-butyl phenol of the ${ }^{\mathrm{P}} \mathrm{PhI}$ derived oxidant responsible for the $\mathrm{O}-\mathrm{O}$ bond formation reaction. Moreover, the rate of formation of $\mathbf{3}$ was found to be enhanced in presence of bridging carboxylates (Fig. 1 bottom), which implies that more than one iron center is involved in the O-O bond formation step. Accordingly, we suggest a radical coupled mechanism for the formation of $\mathbf{3}$, similar to what was proposed earlier for the ruthenium catalyzed O-O bond coupling reaction. ${ }^{26}$ Such a mechanism, however, warrants the initial formation of a peroxo bridged diiron(III) complex, which would then undergo homolysis of the $\mathrm{Fe}^{\mathrm{III}}-\left(\mathrm{O}_{2}{ }^{2-}\right)-\mathrm{Fe}^{\mathrm{III}}$ bond to generate the $\mathrm{Fe}^{\mathrm{II}}\left(\mathrm{O}_{2}{ }^{-}\right)-$ $\mathrm{Fe}^{\mathrm{III}}$ unit in 3 (Scheme 2). DFT calculations were performed to assess the viability of the peroxo complex with our ligand system. We designed a simplified system containing two monomeric units, where the positions of the carboxylate oxygens were frozen in order to mimic the constraints provided by the stannoxane core of 1. The optimized structure (Scheme 2, Fig. S11 and Table S5) reveals two antiferromagnetically coupled $\mathrm{S}=1 / 2 \mathrm{Fe}(\mathrm{III})$ centers in a $\mathrm{Fe}^{\mathrm{III}}-\mathrm{O}-\mathrm{O}-\mathrm{Fe}^{\mathrm{III}}$ unit with the O-O distance of $1.48 \AA$ and $\mathrm{Fe}-\mathrm{O}$ distances of 1.81 and $1.85 \AA$, which are characteristic of peroxo complexes. ${ }^{27}$ This result establishes the peroxo species as a viable intermediate in Scheme 2.

In conclusion, the present results together with the recent report ${ }^{28}$ of an iron-based efficient water oxidation catalyst show that iron like ruthenium can also perform O-O bond formation reaction, a finding of extreme importance in the design and discovery of faster water oxidation catalysts involving biologically innocuous, inexpensive elements.

\section{Acknowledgements}

We gratefully acknowledge financial support of this work from the Cluster of Excellence "Unifying Concepts in Catalysis" (EXC 314/1), Marie Curie Fellowships (PIEF-GA-2008-221734 and 236013), the Polish Ministry of Science (N N 204 215634), the Generalitat de Catalunya (2009SGR528) and MEC-Spain (CTQ200806696/BQU). We thank Prof. Christian Limberg, Prof. Lawrence Que Jr., and Prof. Miquel Costas for helpful discussions, Prof. Reinhard Stößer for EPR measurements, and Mr. Matthias Ziehe for ICP-MS measurements.

\section{Keywords:Polynuclear ligand•stannoxane core•iron complex $\bullet \mathrm{O}-\mathrm{O}$ bond formation $\bullet$ iron (IV) oxo intermediate}

[1] (a) J. W. J. Knapen, A. W. Made, J. C. Wilde, P. W. N. M. Leeuwen, P. Wljkens, D. M. Grove, G. Koten, Nature 1994, 372, 659; (b) H. P. Dijkstra, P. Steenwinkel, D. M. Grove, M. Lutz, A. L. Spek, G. Koten, Angew. Chem. Int. Ed. 1999, 38, 2186; (c) V. Balzani, A. Juris, M. Venturi, Chem. Rev. 1996, 96, 759.

[2] (a) G. Denti, S. Campagna, S. Serroni, A. Juris, M. Ciano, V. Balzani, In Perspectives in Coordination Chemistry; A. F. Williams, C. Floriani, A. E.
Merbach, Eds.; VCH: Basel, Switzerland, 1992 pp. 153; (b) V. Chandrasekhar, S. Nagendran, R. Azhakar, M. R. Kumar, A. Srinivasan, K. Ray, T. K. Chandrashekar, C. Madhavaiah, S. Verma, U. D. Priyakumar, G. N. Sastry, J. Am. Chem. Soc. 2005, 127, 2410.

[3] (a) Y. Gao, T. Åkermark, J. Liu, L. Sun, B. Åkermark, J. Am. Chem. Soc. 2009, 131, 8726; (b) S. H. Kim, H. Park, M. S. Seo, M. Kubo, T. Ogura, J. Klajn, D. T. Gryko, J. S. Valentine, W. Nam, J. Am. Chem. Soc. 2010, 132, 14030; (c) J. P. Roth, C. J. Cramer, J. Am. Chem. Soc. 2008, 130, 7802; (d) H. Furutachi, K. Hashimoto, S. Nagatomo, T. Endo, S. Fujinami, Y. Watanabe, T. Kitagawa, M. Suzuki, J. Am. Chem. Soc. 2005, 127, 4550.

[4] (a) P. E. M. Siegbahn, Inorg. Chem. 2008, 47, 1779; (b) V. L. Pecoraro, and W.-Y. Hsieh, Inorg. Chem. 2008, 47, 1765.

[5] N. S. Lewis, D. G. Nocera, Proc. Natl. Acad. Sci. 2006, 103, 15729.

[6] Single crystal-structure and refinement data for $\mathbf{1}$ and $\left[\mathrm{Fe}^{\mathrm{II}}(\mathrm{L} 2)\left(\mathrm{CH}_{3} \mathrm{CN}\right)_{2}\right](\mathrm{OTf})_{2}: \quad$ a) $\mathrm{C}_{168} \mathrm{H}_{204} \mathrm{Cl}_{24} \mathrm{~N}_{24} \mathrm{O}_{18} \mathrm{Sn}_{6} \quad$ (1), $\mathrm{M}_{\mathrm{w}}=4410.49$, trigonal, space group $R-3, \mathrm{a}=31.2532(6), \mathrm{b}=31.2532(6), \mathrm{c}=17.3497(4) \AA$, $\alpha=90, \quad \beta=90, \quad \gamma=120^{\circ}, \quad V=14676.1(5) \AA^{3}, \quad Z=3 ; \quad$ b) $C_{20} H_{24} F_{6} F_{e N} \mathrm{O}_{6} \mathrm{~S}_{2}$, $\mathrm{M}_{\mathrm{w}}=678.42$, Monoclinic, space group $P 2 \mathrm{1} / \mathrm{n}, \mathrm{a}=12.7951(8), \mathrm{b}=11.5022(7)$, $\mathrm{C}=18.8535(9) \AA, \alpha=90, \beta=95.975(5), \gamma=90^{\circ}, V=2759.6(3) \AA^{3}, \mathrm{Z}=4$ Further experimental details are provided in the Supporting Information. CCDC 818334 for 1 and CCDC 818336 for [ $\left.\mathrm{Fe}^{\mathrm{II}}(\mathrm{L} 2)\left(\mathrm{CH}_{3} \mathrm{CN}\right)_{2}\right](\mathrm{OTf})_{2}$ contain the supplementary crystallographic data for this paper. These data can be obtained free of charge from The Cambridge Crystallographic Data Centre via www.ccdc.cam.ac.uk/data_request/cif.

[7] (a) V. Chandrasekhar, S. Nagendran, S. Bansal, M. A. Kozee, D. R. Powell, Angew. Chem. Int. Ed. 2000, 39, 1833; (b) R. R. Holmes, C. G. Schmid, V. Chandrasekhar, R. O. Day, J. M. Holmes, J. Am. Chem. Soc. 1987, 109, 1408.

[8] D. Pijper, P. Saisaha, J. W. de Boer, R. Hoen, C. Smit, A. Meetsma, R. Hage, R. P. van Summeren, P. L. Alsters, B. L. Feringa, W. R. Browne, Dalton. Trans. 2010, 39, 10375.

[9] The molecular ion peaks of $\mathbf{2}$ and $\mathbf{3}$ were not observable in ESI-MS, possibly because of their large molecular weights. Interestingly, the fragmentation pattern of $\mathbf{2}$ and $\mathbf{3}$ is found to be very similar (Fig. S12), thereby implying the possible loss of oxygen from 3 to yield 2 under the conditions of ESI-MS. MALDI-TOF experiments to detect the molecular ions of $\mathbf{2}$ and $\mathbf{3}$ were also unsuccessful.

[10] R. Sustmann, H.-G. Korth, D. Kobus, J. Baute, K.-H. Seiffert, E. Verheggen, E. Bill, M. Kirsch, H. Groot, Inorg. Chem. 2007, 46, 11416.

[11] The minor component (25\%) is Fe(II) low-spin with $\delta=0.49 \mathrm{~mm} \mathrm{~s}^{-1}$ and $\Delta \mathrm{E}_{0}$ $=0.41 \mathrm{~mm} \mathrm{~s}^{-1}$. In $\mathrm{CH}_{3} \mathrm{CN}$ solution only the low spin signal with $\delta=0.46 \mathrm{~mm}$ $\mathrm{s}^{-1}$ and $\Delta \mathrm{EQ}_{\mathrm{Q}}=0.29 \mathrm{~mm} \mathrm{~s}^{-1}$ is obtained.

[12] See supporting information for details.

[13] a) W.G. Han, L. Noodleman, Inorg. Chem. 2008, 47, 2975; b) W.G. Han, T.Q. Liu, T. Lovell, L. Noodleman, J. Comput. Chem. 2006, 27, 1292; c) W.G. Han, L. Noodleman, Inorg. Chim. Acta 2008, 361, 973.

[14] (a) J.-U. Rohde, L. Que, Jr., Angew. Chem. Int. Ed. 2005, 44, 2255; (b) L. Que, Jr., Acc. Chem. Res. 2007, 40, 493; (c) K. Ray, S. M. Lee, L. Que, Jr., Inorg. Chim. Acta. 2008, 361, 1066.

[15] IR spectra of $\mathbf{2}$ and $\mathbf{3}$ show the characteristic v(COO) and v(Sn-O) stretches of the $\mathrm{Sn}_{6} \mathrm{O}_{6}$ core; thus the drum structure of $\mathbf{1}$ is retained in $\mathbf{2}$ and $\mathbf{3}$ (Fig. S2). The additional band at $\sim 635 \mathrm{~cm}^{-1}$ for 2 and 3 originates from the triflate anions.

[16] (a) P. K. Grzyska, E. H. Appelman, R. P. Hausinger, D. A. Proshlyakov, Proc. Natl. Acad. Sci. 2010, 107, 3982; (b) J. M. Bollinger, Jr., J. C. Price, L. M. Hoffart, E. W. Barr, C. Krebs, Eur. J. Inorg. Chem. 2005, 4245.

[17] From statistical distribution the band at $1144 \mathrm{~cm}^{-1}\left(3^{-16} \mathrm{O}-{ }^{18} \mathrm{O}\right)$ is expected to be twice as intense as the $1173 \mathrm{~cm}^{-1}\left(3^{-16} \mathrm{O}-{ }^{16} \mathrm{O}\right)$ and $1116 \mathrm{~cm}^{-1}\left(3_{-}{ }^{16} \mathrm{O}-{ }^{16} \mathrm{O}\right)$ bands. The lowered intensity of the $1144 \mathrm{~cm}^{-1}$ band in the experimental spectrum is not understood at present.

[18] No satisfactory simulation of the $3-{ }^{16} \mathrm{O}-{ }^{18} \mathrm{O}$ spectrum with a split peak by keeping the positions and width $\left(33 \mathrm{~cm}^{-1}\right)$ of the oxygen insensitive bands at $1158 \mathrm{~cm}^{-1}$ and $1138 \mathrm{~cm}^{-1}$ could be obtained; an unreasonable fit by changing the position $\left(1161 \mathrm{~cm}^{-1}\right)$ and width $\left(26 \mathrm{~cm}^{-1}\right)$ of the $1158 \mathrm{~cm}^{-1}$ is shown in Figure S14.

[18] The superoxo unit can be terminal or bridging $\left(\mu-\eta^{1} \eta^{2}, \mu-1,2\right.$ or $\left.\mu-\eta^{2} \eta^{2}\right)$ (Scheme S3, Table S2) but presently we do not have any spectroscopic evidence to discern between the four possibilities. However, based on the thermal stability of 3 , which allowed its generation at $25{ }^{\circ} \mathrm{C}$, we favour a terminal binding mode with the superoxide unit attached to $\mathrm{Fe}^{\mathrm{III}}$ only and not 
interacting with $\mathrm{Fe}^{\mathrm{II}}$. The very few examples of $\mathrm{Fe}^{\mathrm{II}} \mathrm{O}_{2}{ }^{\bullet}{ }^{-} \mathrm{Fe}^{\mathrm{III}}$ bridging complexes are highly unstable against the intramolecular electron transfer from $\mathrm{Fe}^{\mathrm{II}}$ to $\mathrm{O}_{2}{ }^{\bullet-}$, to form a more symmetric $\mathrm{Fe}^{\mathrm{III}} \mathrm{O}_{2}{ }^{2-} \mathrm{Fe}^{\mathrm{III}}$ unit. For instance, this is the case for the transient $\mathrm{Fe}^{\mathrm{II}} \mathrm{O}_{2}{ }^{\bullet} \mathrm{Fe}^{\mathrm{III}}$ superoxo units in soluble methane monooxygense (which is not yet isolated) and a synthetic model complex (which is only stable at low-temperature and decays to diiron(III) species at elevated temperatures), where a $\mu-\eta^{1} \eta^{2}$ bridging mode has been proposed based on DFT (D. Rinaldo, D. M. Philipp, S. J. Lippard, R. A. Friesner, J. Am. Chem. Soc. 2007, 129, 3135) and experiments (M. Zhao, B. Helms, E. Slonkina, S. Friedle, D. Lee, J. DuBois, B. Hedman, K. O. Hodgson, J. M. J. Fréchet, S. J. Lippard, J. Am. Chem. Soc. 2008, 130, 4352), respectively. Interestingly, a terminal end-on $\mathrm{Fe}^{\mathrm{II}}\left(\mathrm{O}_{2}{ }^{\bullet}\right)-\mathrm{Fe}^{\mathrm{III}}$ superoxo complex is also reported to be of transient nature (X. Shan, L. Que, Jr. Proc. Natl. Acad. Sci. 2005, 102, 5340).

[19] Hydroxide, iodide, bromide, or chloride, in contrast, retarded the conversion of 2 to 3 .

[20] a) X. Shan, L. Que, Jr., Proc. Natl. Acad. Sci. 2005, 102, 5340; b) D. Maiti, D.-H. Lee, K. Gaoutchenova, C. Würtele, M. C. Holthausen, A. A. N. Sarjeant, J. Sundermeyer, S. Schindler, K. D. Karlin, Angew. Chem. Int. Ed. 2008, 47, 82 .

[21] Y.-R. Luo, In Compresensive Handbook of Chemical Bond Energies Taylor \& Francis, 2007; pp. 255.

[22] A. Paul, J. F. Hull, M. R. Norris, Z. Chen, D. H. Ess, J. J. Concepcion, T. J. Meyer, Inorg. Chem. 2011, 50, 1167
[24] Control reactions of benzyl alcohol and 2,4,6-tri-tert-butyl phenol performed with preformed 3 and with ${ }^{\mathrm{s}} \mathrm{PhIO}$ at $-80{ }^{\circ} \mathrm{C}$ did not lead to the formation of any benzaldehyde or 2,4,6-tri-tert-butyl phenoxyl radical.

[25] Unfortunately, it has not been possible to ascertain the iron oxidation state in 3 by Mössbauer spectroscopy because it is formed only in $\mathrm{CH}_{2} \mathrm{Cl}_{2}$, a solvent that severely hampers the application of this technique.

[26] S. Romain, F. Bozoglian, X. Sala, A. Llobet, J. Am. Chem. Soc. 2009, 131, 2768.

[27] M. R. A. Blomberg, A.J. Johansson, P.E.M. Siegbahn, Inorg. Chem. 2007, 46 7992

[28] a) W. C. Ellis, N. D. McDaniel, S. Bernhard, T. J. Collins, J. Am. Chem. Soc. 2010, 132, 10990; b) J. L. Fillol, Z. Codolà, I.G.-Bosch, L. Gómez, J. J. Pla M. Costas, Nature Chemistry, 2011, 3, 807.

Received: ((will be filled in by the editorial staff)) Revised: ((will be filled in by the editorial staff)) Published online: ((will be filled in by the editorial staff)) 
O-O bond formation-____-_

S. Kundu, E. Matito, S. Walleck, F. F. Pfaff, F. Heims, B. Rábay, J. M. Luis, A. Company, B. Braun, T.

Glaser, K. Ray* Page - Page

O-O Bond Formation Mediated by a Hexanuclear Iron Complex Supported on a Stannoxane Core

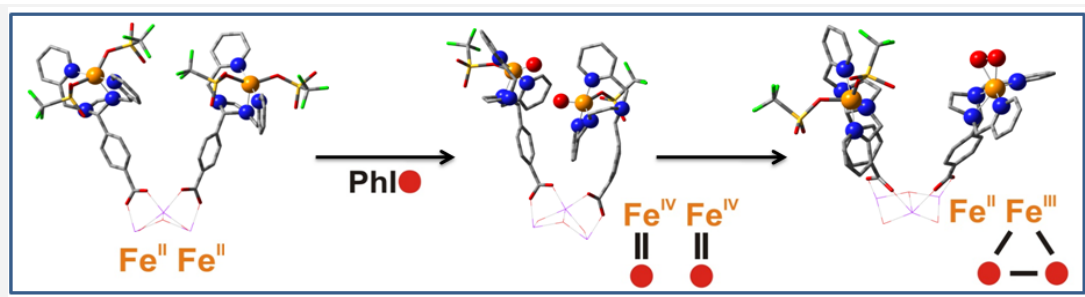

The Fe ${ }^{\mathrm{II}}$ complex of a hexanuclear coupled $\mathrm{O}-\mathrm{O}$ bond formation non-heme ligand system is reported mechanism is proposed (see to perform an O-O bond formation scheme). Thus iron like ruthenium reaction using iodosobenzene as the can also perform O-O bond oxygen source. In contrast, the formation, a finding of extreme mononuclear $\mathrm{Fe}^{\mathrm{II}}$ complex importance in the design and underwent decomposition reaction. discovery of faster and cheaper On the basis of infrared, UV-Vis, water oxidation catalysts.. kinetic and DFT studies a radical

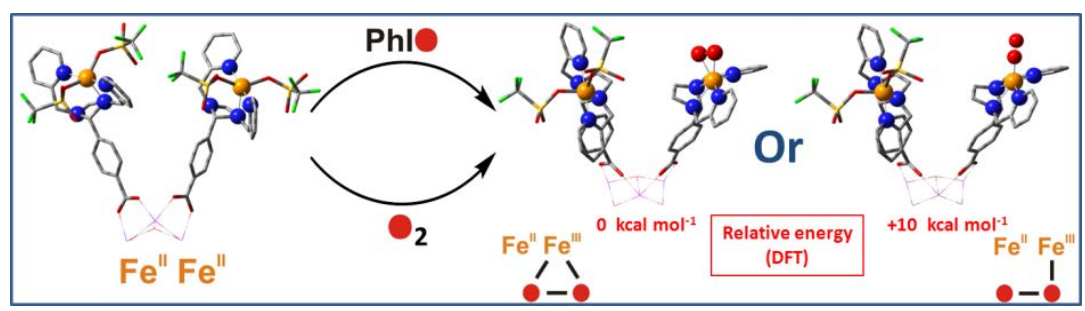

